\title{
DMSO and sucrose combination as a cryoprotectant of Najawa carp (Cyprinus carpio L.) sperm cryopreservation
}

\author{
Lenggang Mamitu Krisdahasti, Ignatius Hardaningsih, and Dini Wahyu Kartika Sari* \\ Aquaculture Study Program, Fisheries Department, Universitas Gadjah Mada. \\ *Corresponding author: dini.sari@ugm.ac.id
}

\begin{abstract}
This study was designed to evaluate a DMSO (Dimethyl Sulfoxide) and sucrose combination as a cryoprotectant for cryopreservation of Najawa carp (Cyprinus carpio L.) sperm. The experiment was conducted according to the Completely Randomized Design (CRD) with four treatments 10\% DMSO + 0.2 M sucrose, $10 \%$ $\mathrm{DMSO}+0.1 \mathrm{M}$ sucrose, $5 \% \mathrm{DMSO}+0.2 \mathrm{M}$ sucrose, $5 \% \mathrm{DMSO}+0.1 \mathrm{M}$ sucrose. Each treatment consisted of three replications. The parameter observed were sperm progressive motility of fresh sperm, diluted sperm before freezing, and diluted sperm after freezing 1 day; 7 days; 14 days; 21 days; 28 days. The data were analyzed by ANOVA. The result showed that there was no significant difference between treatments (Sig. $>0.05$ ). The highest relative protection was $89.51 \%$ carried out by $5 \%$ DMSO $+0.1 \mathrm{M}$ sucrose.
\end{abstract}

\section{Introduction}

Najawa carp is developed by Balai Pengembangan Teknologi Perikanan Budidaya (BPTPB) Cangkringan, Yogyakarta with red color characteristics on their body [1]. Carp generally spawns optimally in the early rainy season, but in some cases, sperm and eggs do not mature at the same time. Sperm preservation during the peak of sperm maturity season can be addressed to overcome this problem. The carp sperm can be stored for a long time and can be used anytime the eggs are ready.

Cryopreservation is a method to preserve cell and tissue for a long time at a very low temperature. Cryopreservation requires an important solution, an extender solution and a cryoprotectant. The extender has a function as nutrients, $\mathrm{pH}$ regulators and sperm osmotic pressure, and cryoprotectant is essential to protect the cell from very low-temperature damage [2].

Cryoprotectant has two types, permeating cryoprotectant and non-permeating cryoprotectant. Permeating cryoprotectant will give protection from inside the cell such as DMSO, glycerol, DMF, etc. On the other hand, non-permeating will protect the cell from outside such as BSA, skim milk, egg yolk, sucrose, glucose, fructose, etc $[3,4,5,6,7,8]$. A combination of permeating and non-permeating cryoprotectants was expected to provide double protection for the cell during cryopreservation. 
Our previous study [9] compared double protection (DMSO and sucrose), inside single protection (DMSO), outside single protection (sucrose), and without protection (without cryoprotectant) for carp sperm cryopreservation.

Although gave protection during cryopreservation, the double protection did not give higher protection compared with the single protection. In this case, we assumed that the concentration of the preservation solution was still too high. In this study, we tried to find out the best concentration of DMSO and sucrose combination as a cryoprotectant for cryopreservation of Najawa carp (Cyprinus carpio L.) sperm.

\section{Method}

\subsection{Treatments:}

1. $10 \% \mathrm{DMSO}+0.2 \mathrm{M}$ sucrose

2. $10 \% \mathrm{DMSO}+0.1 \mathrm{M}$ sucrose

3. $5 \% \mathrm{DMSO}+0.2 \mathrm{M}$ sucrose

4. $5 \% \mathrm{DMSO}+0.1 \mathrm{M}$ sucrose

Each treatment consists of 3 replications.

\subsection{Extender solution and cryoprotectants:}

Extender solution: Iwamatsu BSS [10] with $\mathrm{pH}$ modification (same as an internal environment of carp sperm $\mathrm{pH}(6.8))$

Cryoprotectant: DMSO (permeating cryoprotectant) and sucrose (non permeating cryoprotectant)

\subsection{Sperm collection:}

Sperm was collected from Najawa carp broodstock by squeezing method and diluted in the treatment solution in a ratio of $1: 9$

\subsection{Fresh sperm evaluation:}

Fresh sperm was checked for color, $\mathrm{pH}$, consistency, individual motility, mass movement, and sperm concentration. The standard motility used in the study was $>$ $50 \%$, the sperm motility $\leq 50 \%$ was not used for cryopreservation.

\subsection{Cryopreservation:}

Diluted sperm in the treatment solution was put in a $0.25 \mathrm{ml}$ straw in the fillingsealing process and stored in a cool box $\left(4^{\circ} \mathrm{C}\right)$. And then, the temperature was decreased gradually by putting the sample as high as $5 \mathrm{~cm}$ above the liquid nitrogen for 10 minutes (exposed the sample in liquid nitrogen vapor). Finally, the sample was dipped into liquid nitrogen $\left(-196^{\circ} \mathrm{C}\right)$ and stored for 28 days.

\subsection{Sperm function evaluation:}

Sperm motility was observed before and after freezing (1 day, 7 days, 14 days, 21 days, and 28 days). The frozen sperm was thawed at $30^{\circ} \mathrm{C}$ for 10 seconds before checking the sperm motility after cryopreservation.

\subsection{Data analysis:}

The data were analyzed by using ANOVA with $p<0.05$ level of significance. 


\section{Result}

\subsection{Fresh sperm}

Fresh sperm of Najawa carp directly observed after squeezing to evaluate the quality of the sperm before cryopreservation. The data (Table 1) showed that Najawa fresh sperm had a milky white color, thick consistency, $76.67 \%$ motility, $3(+++)$ mass movement, and $4.88 \mathrm{x}$ $10^{9}$ cells $/ \mathrm{ml}$. Based on the data, the fresh sperm had a very good quality [11] for further cryopreservation processing.

Table 1. Fresh sperm characteristics of Najawa carp

\begin{tabular}{|l|l|}
\hline Sperm parameters & Characteristics \\
\hline Color & Milky white \\
\hline $\mathrm{pH}$ & 6.8 \\
\hline Consistency & Thick \\
\hline Motility & $76.67 \%$ \\
\hline Mass movement & $3(+++)$ \\
\hline Consentration & $4.88 \times 10^{9}$ cells $/ \mathrm{ml}$ \\
\hline
\end{tabular}

\section{a. Sperm motility before and after cryopreservation}

Sperm motility is the parameter most commonly used to evaluate sperm function in fish. Figure 1 showed that there were significant differences in sperm motility between fresh sperm and diluted sperm after freezing, but no significant differences between treatments. The highest sperm motility until 28 days cryopreservation, $50.56 \%$, was carried out by $5 \%$ $\mathrm{DMSO}+0.1 \mathrm{M}$ sucrose.

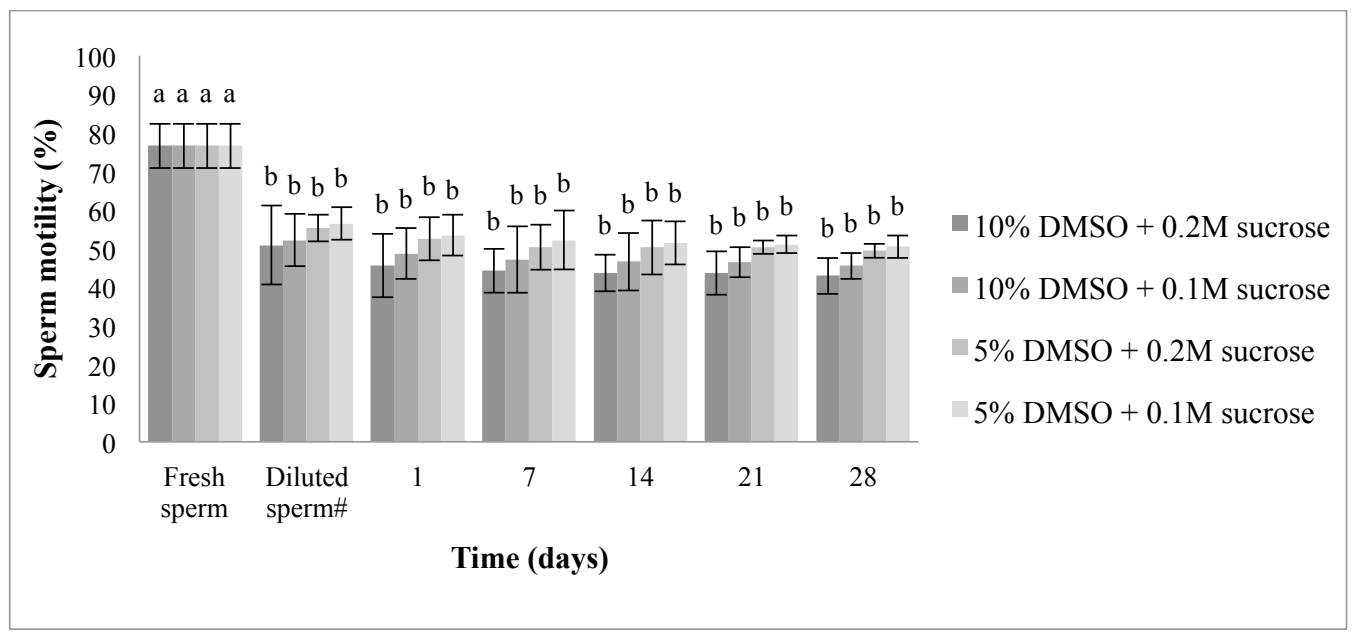

Figure 1. Sperm motility before and after cryopreservation. Fresh sperm and Diluted sperm\# were the sperm motility before cryopreservation. Numbers (time days $1,7,14,21,28$ ) were sperm motility after cryopreservation period. Data were presented as mean \pm SD. Different letters indicate statistically significant differences in sperm motility before the cryopreservation period in the same treatment $(\mathrm{P}<0.05)$. 


\subsection{Relative percent protection of the cryoprotectants}

Relative motility of sperm was obtained by comparing motility of the sperm at 28 days cryopreservation with motility before freezing. Figure 2 showed that although there were no significant differences between the treatments, relative protection of the cryoprotectant increased gradually by reducing the concentration of the cryoprotectant combinations. The highest relative percent protection was carried out by $5 \% \mathrm{DMSO}+0.1 \mathrm{M}$ sucrose $(89.51 \%)$.

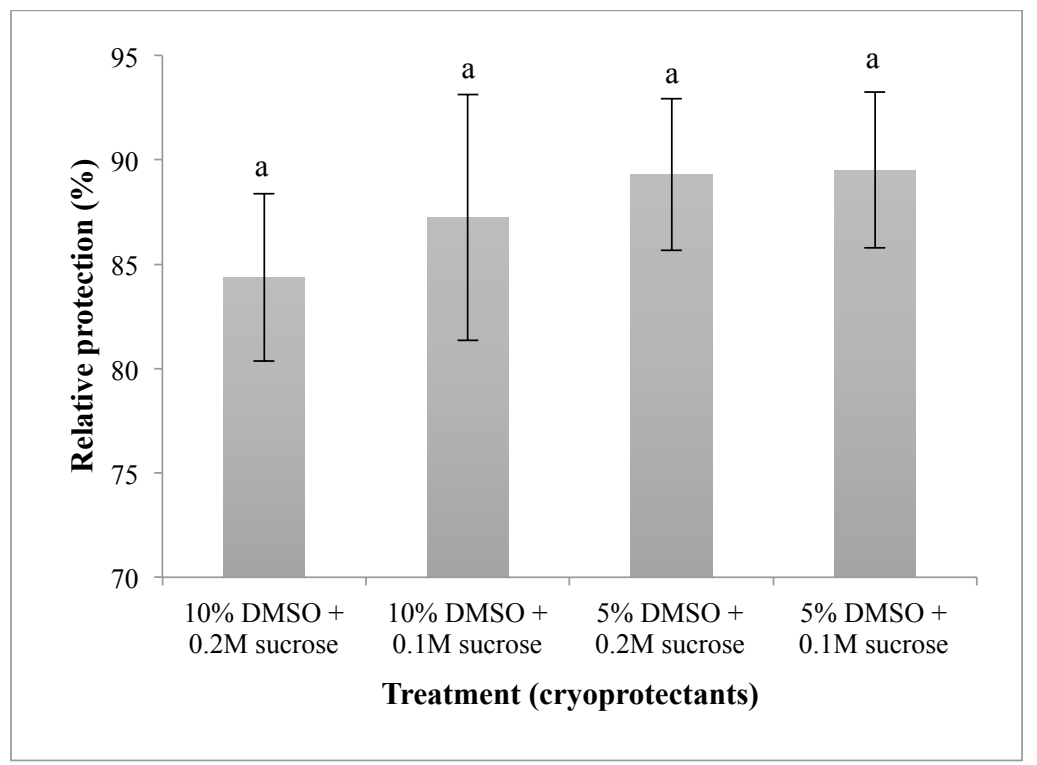

Figure 2. Relative percent protection of the cryoprotectants. Data were presented as mean $\pm \mathrm{SD}$. The same letter indicate statistically no significant differences between treatments in the 28 days cryopreservation period $(\mathrm{P}<0.05)$.

\section{Discussion}

Although there was no significant difference between the treatments, the combination of 5\% DMSO and 0,1 M sucrose had better protection for Najawa carp sperm than other higher dose combinations (Figure 1 and Figure 2) during cryopreservation. A high concentration of cryoprotectant can cause cell damage due to osmotic stress or toxic effects [12].

In an appropriate concentration, sucrose can improve the cell dehydration and effectively reduce intracellular ice formation in a shorter period, but high sucrose concentration can reduced sperm motility because high viscosity of the medium might inhibit normal sperm motility [13].

Najawa carp sperm motility decreased significantly before freezing. But after freezing at very low temperature $\left(\sim 196^{\circ} \mathrm{C}\right)$, sperm motility was stable until 28 days experiment (Fig. 1). Sperm cells protected by appropriate cryoprotectants will survive from low-temperature damage. In this case, the cryoprotectant combinations in all treatments were suitable enough to protect the sperm cells. Protected sperm cells were stable until the end of the cryopreservation period and it could be longer since the metabolism of the sperm was stopped and the sperm well protected. Between all of the treatments, the highest protection achieved by $5 \%$ DMSO and $0,1 \mathrm{M}$ sucrose with $89.51 \%$ relative percent protection. 
Contrast with the constant sperm motility after freezing, there were significant decline of fresh sperm and diluted sperm motility before freezing. The percentage of the declining sperm motility reached $30 \%-50 \%$ ((Fig. 1, $[9,14])$. Pre-conditioning of the sperm became the critical point of sperm cryopreservation. Further pre-conditioning study is needed to overcome this problem.

\section{Acknowledgement}

We are grateful to Dr. Djumanto for critical discussion and we also thank to Rohana Hidayati for critically reading the paper. This work was supported by Hibah Fakultas Pertanian UGM, Indonesia (Grants-in-Aid for Scientific Research from the Agriculture Faculty UGM).

\section{References}

1. E. Nugroho, D. Priyanto, H. S. Hermawan, Sunaryo, and A.S. Prihadi. Phenotype and genotype characters of red Najawa from Cangkringan Yogyakarta and its economic potential. Media Akuakultur 10(1):13-16 (2015)

2. J.C. Gwo. Cryopreservation of Sperm of Some Marine Fishes, in Tiersch, T.R. and Mazik, P.M. (Eds.), Cryopreservation in Aquatic Species. World Aquaculture Society, Baton Rouge, L.A. 138-160 (2000)

3. P.C. Chew and Abd. R. Zulkafli. Sperm Cryopreservation of Some Freshwater Fish Species in Malaysia. Agricultural and Biological Sciences: "Current Frontiers in Cryopreservation" (2012)

4. A. Sadeghi, and M.R. Imanpoor. Effect of Use of Combinations of Permeating Cryoprotectant (MeOH, DMSO) and Non Permeating Cryoprotectant (BSA) on Viability of Beluga (Huso huso) Post-Thawed Sperm. Worl Journal of Fish and Marine Scinces, 5(6): 593-597 (2013)

5. Y. Bozkurt, I. Yavas, and C. Yaldaz. Effect of Different Avian Egg Yolk Types on Fertilization Ability of Cryopreserved Common Carp (Cyprinus carpio) Spermatozoa. Aquaculture Int. 22 : 131-139 (2014)

6. I. Yavas, Y. Bozkurt, and C. Yaldaz. Cryopreservation of Scaly Carp (Cyprinus carpio) Sperm: Effect of Different Cryoprotectant Concentration on Post Thaw Motility, Fertilization and Hatching Success of Embryos. Aquaculture Int. 22:141-148 (2014)

7. G. Chong, S. Tsai., L. H. Wang, C. Y. Huang, and C. Lin, Cryopreservation of the gorgonian endosymbiont Symbiodinium, Scientific Report 6 : 1-9 (2016.)

8. T., da S. Lopes, E. Romagosa, D. P. Streit Jr, R. P. Ribeiro, and M. Digmayer, Cooling of pacu (Piaractus mesopotamicus) embryos at various stages of development for 6 or 10 hours, Theriogenology 75: 570-576 (2011)

9. A. A. Prakoso. Punten carp (Cyprinus carpio L.) sperm cryopreservation by using sucrose and DMSO cryoprotectant. Thesis. Fisheries Department, Agriculture Faculty, Universitas Gadjah Mada (2018)

10. K. Aoki, M. Okamoto, K. Tatsumi, and Y. Ishikawa. Cryopreservation of Medaka Spermatozoa. Zoological Science, 14: 641-644 (1997) 
11. M. E. McMaster, C. B. Port., K. R. Munkittrick., D. G. Dixon. Milt Characteristics, Reproductive Performance, and Larval Survival and Development of White Sucker Exposed to Bleached Kraft Milt Effluent. Ecotoxicology and Enviromental Safety. 23: 103-117 (1992)

12. R. Widyastuti, C. Khorinaya, M.R. Ridlo, dan M. R. A. A. Syamsunarno. Comparison of oocyte viability after vitrification with two different sucrose concentration level. MKB 49(4): 252-258 (2017)

13. C. Consuegra, F. Crespo, M. Bottrel, I. Ortiz, J. Dorado, M. Diaz-Jimenez, B. Pereira, M. Hidalgo, Stallion sperm freezing with sucrose extenders: a strategy to avoid permeable cryoprotectants, Elsevier Animal Reproduction Science 191: 85-91 (2018)

14. I. D. Setyarini, Punten carp (Cyprinus carpio L.) sperm cryopreservation by using BSA and DMSO cryoprotectant. Thesis. Fisheries Department, Agriculture Faculty, Universitas Gadjah Mada (2018) 